\title{
Analisis Penerapan Metode 'Allimna untuk Mempercepat Baca Al-Qur’an
}

\author{
Abdul Havid, Moch. Shohib ${ }^{2}$ \\ ${ }^{1}$ Institut Agama Islam Syarifuddin Lumajang, Indonesia \\ ${ }^{2}$ Institut Agama Islam Syarifuddin Lumajang, Indonesia \\ 1abdulhavid31@gmail.com
}

doi) DOI: 10.37542/iq.v4i01.150

\begin{abstract}
Studying and understanding the Qur'an and teaching it is a very high value worship. Learning the Qur'an is the best of Muslims and teaching the Qur'an to others is also the best of Muslims, both of these things are equally good but it will be better and more important if someone combines the two. The focus of the problem in this study 1) What is the 'Allimna method to speed up reading the Qur'an? 2) How is the application of the 'Allimna method to speed up reading the Qur'an? 3) What are the inhibiting and supporting factors of the 'Allimna method to speed up reading the Qur'an?. This study uses a qualitative-descriptive method, using a case study approach. Data collection techniques are interviews, observations, and documentation. The results of the study show that the 'Allimna method is the 'Allimna method not only offering a fast method, it turns out that the choices of the 'Allimna verse are many of the arguments for the akidah and amaliyah of Ahlussunnah Wal Jama'ah. The purpose of using the 'allimna method is to achieve better results and the first steps are in recognizing the Hijaiah letters and their makhroj, the second is the introduction of harokah, the third is the introduction of serial letters and the fourth is the introduction of the science of tajweed. The inhibiting factor for the 'Allimna method is that there are students who are lazy to repeat or re-learn lessons at home, along with tutoring activities. Supporting factors for students, students are diligent in every learning process at TPQ Al-Barokah.
\end{abstract}

Keywords: 'Allimna Method, How to Read Al-Qur'an, TPQ 


\begin{abstract}
Abstrak
Mempelajari dan memahami Al-Qur'an serta mengajarkannya merupakan suatu ibadah yang sangat tinggi nilainya. Belajar Al-Qur'an adalah sebaik-baik orang muslim dan mengajarkan Al-Qur'an kepada orang lain juga sebaik-baik orang muslim, kedua hal tersebut sama- sama baik tetapi akan lebih baik dan utama lagi jika seseorang menggabungkan keduanya. Fokus Masalah dalam penelitian ini 1) Apa yang dimaksud metode 'Allimna untuk mempercepat baca Al-Qur'an? 2) Bagaimana penerapan metode 'Allimna untuk mempercepat baca Al-Qur'an? 3) Apa yang menjadi faktor penghambat dan pendukung metode 'Allimna untuk mempercepat baca Al-Qur'an?. Penelitian ini menggunakan metode kualitatif-deskriptip, dengan menggunakan pendekatan studi kasus. Teknik pengumpulan data wawancara, observasi, dan dokumentasi. Hasil penelitian menunjukan Metode 'Allimna adalah Metode 'Allimna tidak hanya menawarkan metode cepat, ternyata pilihan-pilhan ayat 'Allimna banyak yang menjadi argumentasi akidah dan amaliyah Ahlussunnah Wal Jama'ah. Maksud penggunaan metode 'allimna agar dapat mencapai hasil yang lebih baik dan langkah-langkah yang pertama dalam melakukan pengenalan huruf Hijaiah dan makhrojnya, kedua adalah pengenalan harokah, ketiga adalah pengenalan huruf bersambung dan keempat pengenalan ilmu Tajwid. Faktor penghambat metode 'Allimna dikarenakan adanya santri yang malas untuk mengulang atau mempelajari kembali pelajaran di rumah, bersamaan dengan kegiatan les. Faktor Pendukung peserta didik, para santri rajin dalam setiap mengikuti pembelajaran di TPQ Al-Barokah.
\end{abstract}

Kata Kunci: Metode ‘Allimna, Cara Baca Al-Qur’an, TPQ

\title{
Pendahuluan
}

Al-Qu'ran adalah Kalamullah yang diturunkan kepada Nabi Muhammad SAW dan membacanya adalah ibadah. ${ }^{1}$ Menurut Subhi al-Shalih definisi al-Qur'an adalah Firman Allah yang bersifat mukjizat (sebagai bukti kebenaran atas kenabian Muhammad saw.) yang diturunkan pada Nabi Muhammad saw., yang tertulis di dalam mushaf-mushaf yang dinukil (diriwayatkan) dengan jalan mutawatir, dan yang membacanya dipandang beribadah. ${ }^{2}$

Bahwa hal tersebut menunjukkan sejak awal agama Islam sudah menyerukan kepada manusia untuk membaca. Karena dengan membaca akan memperoleh informasi yang mencangkup isi dan memahami makna bacaan. Sebab wahyu Allah pun tidak dapat diterima tanpa dibaca terlebih dahulu. Agar umat Islam mampu membaca al-Qur'an dengan benar sesuai

\footnotetext{
${ }^{1}$ Said Abdul Adhim, Nikmatnya Membaca Al-qur'an (Solo: Anggota SPI, 2009), 13.

${ }^{2}$ Masjfuk Zuhdi, Pengantar Ulumul Qur'an (Surabaya: Karya Abditama,1997), 1.

52 | IQ (Ilmu Al-qur'an): Jurnal Pendidikan Islam| Volume 4 No.01 2021, 51-74
} 
dengan kaidah atau aturan yang benar, maka perlu diadakan pembelajaran al-Qur'an bagi seluruh umat Islam. ${ }^{3}$

Al-Qur'an merupakan petunjuk hidup bagi umat Islam di dunia dan akhirat. Mempelajari al-Qur'an sangatlah penting. Karena al-Qur'an dijadikan sebagai pedoman hidup umat Islam. Menurut Hambali dalam bukunya, Cinta Alquran: Para Hafiz Cilik, menyatakan bahwa al-Qur'an adalah kemuliaan yang paling tinggi, yang merupakan pedoman hidup manusia di dunia menuju akhirat. Al-Qur'an adalah mukjizat Islam yang kekal dan selalu diperkuat oleh kemajuan ilmu pengetahuan. Manusia terbaik adalah manusia yang belajar alQur'an dan mengajarkannya. Al-Qur'an menjadi mukjizat terbesar yang diturunkan oleh Allah kepada Rasul-Nya. ${ }^{4}$ Allah menurunkan al-Qur'an kepada Rasulullah SAW untuk mengeluarkan manusia dari jalan yang gelap menuju jalan yang terang. Al-Qur'an juga merupakan petunjuk bagi manusia baik di dunia maupun di akhirat, sebagaimana yang tercantum dalam firman Allah dalam surah al-Baqarah: 2, yang berbunyi:

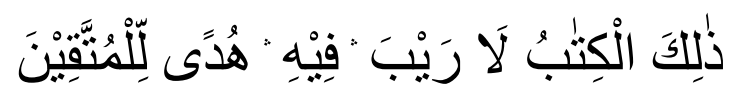

“Kitab (Al-Qur'an) ini tidak ada keraguan padanya, petunjuk bagi mereka yang bertakwa."

Bagi setiap muslim al-Qur'an merupakan kitab suci yang sangat diagungkan karena di dalamnya terdapat nilai-nilai yang penting untuk dijadikan suri teladan maupun sebagai pedoman terhadap segala aspek kehidupan. Sehingga bagi orang-orang Islam apabila ingin mengharap kehidupan yang sejahtera, damai, dan bahagia, maka seharusnya berperilaku sesuai dengan semua hal yang tertera dalam al-Qur'an. ${ }^{5}$ Dengan al-Qur'an kehidupan dapat dijalani dengan baik. Dengan al-Qur'an hal-hal yang baik dan buruk bisa dibedakan, serta mengetahui segala apa pun yang diridai oleh Allah SWT. Al-qur'an sangat penting bagi kehidupan manusia, dengan itu setiap muslim harus mempelajari dan mendalaminya. Bukan hanya sekedar mempelajarinya dalam membacanya pun harus fasih (lancar) dan benar sesuai dengan kaidah atau aturan membaca al-Qur'an.

Kemampuan membaca al-Qur'an dengan baik dan benar bagi umat Islam, merupakan dasar bagi dirinya sendiri atau untuk disampaikan kepada orang lain. Oleh karena itu upaya peningkatan kemampuan membaca al-Qur'an merupakan tuntunan yang mendesak untuk

\footnotetext{
3 Henry Guntur Tarigan, Membaca Sebagai Suatu Keterampilan Berbahasa, (Angkasa Bandung: Bandung,2008), 9.

${ }^{4}$ Hambali, Cinta Al-Qur'an Para Hafizh Cilik (Jogjakarta: Najah, 2013), 5.

${ }^{5}$ Wiwi Alwiyah Wahid, Cara Cepat Bisa Menghafal al-Qur'an (Jogjakarta: DIVA Press, 2014), 6.
} 
dilakukan bagi umat Islam dalam rangka peningkatan, penghayatan dan pengamalan al-Qur'an dalam kehidupan sehari-hari.

Agar umat Islam mampu membaca al-Qur'an dengan fasih (lancar) dan benar sesuai dengan kaidah atau kaidahnya maka perlu diadakan suatu pembelajaran al-Qur'an. Karena apabila membaca al-Qur'an tidak disertai dengan kaidah atau aturan yang benar maka akan berakibat pada kesalahan dalam pemaknaan al-Qur'an. Kaidah yang harus diperhatikan yaitu, ilmu tajwid, makhārij al-ḥurūf (tempat keluarnya huruf), ${ }^{6}$ dan gharīb (bacaan asing dalam Alquran). Aturan yang paling penting yaitu membaca al-Qur'an dengan tartil. Sebagaimana firman Allah dalam surat Muzammil: 4 yang berbunyi:

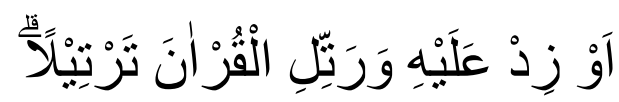

“Atau lebih dari seperdua itu. dan bacalah al-Qur'an itu dengan perlahan-lahan.”

Mempelajari dan memahami al-Qur'an serta mengajarkannya merupakan suatu ibadah yang sangat tinggi nilainya. Belajar al-Qur'an adalah sebaik-baik orang muslim dan mengajarkan al-Qur'an kepada orang lain juga sebaik-baik orang muslim, kedua hal tersebut sama- sama baik tetapi akan lebih baik dan utama lagi jika seseorang menggabungkan keduanya. Maksudnya orang tersebut belajar cara membaca al-Qur'an sekaligus mengajarkannya kepada orang lain apa yang dipelajarinya.

Pembelajaran al-Qur'an yang baik membutuhkan sebuah sistem yang mampu menjamin mutu setiap anak atau orang yang belajar membaca al-Qur'an agar cepat dan mudah membaca al-Qur'an secara baik dan benar. Setiap metode pembelajaran al-Qur'an mempunyai langkah dan cara yang berbeda dalam pelaksanaan pembelajarannya. Demi mewujudkan keberhasilan pembelajaran al-Qur'an para guru (ustaz dan ustazah) membuat berbagai macam metode dan strategi dalam pembelajarannya dengan tujuan agar al-Qur'an mudah dipelajari oleh siapa pun dari berbagai kalangan.

Dalam proses pembelajaran membaca al-Qur'an diperlukan sebuah metode. Sebab, metode mempunyai peranan sangat penting dalam upaya pencapaian tujuan pembelajaran. Dengan menggunakan metode akan mampu mengembangkan sikap mental dan kepribadian agar peserta didik menerima pelajaran dengan mudah, efektif, dan dapat dicerna dengan baik.

Pembelajaran al-Qur'an di kalangan pondok pesantren sudah sering kita jumpai, namun masih sangat jarang sekali TPQ yang menggunakan sebuah metode dalam proses pembelajaran

\footnotetext{
${ }^{6}$ Acep Lim Abdurohim, IlmuTajwid Lengkap (Bandung: CV Penerbit Diponegoro, 2012), 20.
} 
al-Qur'an. Melihat kenyataan yang ada bahwa telah muncul berbagai macam metode pembelajaran al-Qur'an di antaranya metode Iqra', metode Tartil, metode Utsmani, metode Ummi dan mungkin masih ada metode-metode yang lain yang belum diketahui oleh penulis. Pembelajaran Alquran biasanya dijumpai pada lembaga-lembaga pendidikan al-Qur'an seperti TPA, TPQ dan pondok pesantren. Sebagian besar pendidikan al-Qur'an di kalangan TPA dan TPQ sudah menggunakan sebuah metode pembelajaran al-Qur'an, Sementara itu peneliti mengetahui penerapan sebuah metode yang efektif dan efisien dalam pembelajaran Alquran pada santri di TPQ, metode tersebut yaitu metode Allimna. Metode ini diterapkan di Taman Pendidikan al-Qur'an (TPQ) Al-Barokah Kabupaten Jember.

Metode 'Allimna hadir diilhami oleh model-model pengajaran membaca al-Qur'an yang sudah tersebar dimasyarakat, khususnya dari model yang telah sukses mengantar banyak anak bisa membaca al-Qur'an dengan lancar dan cepat. Metode Allimna adalah metode membaca al-Qur'an menggunakan lagu-lagu yang banyak sehingga metode ini akan mudah difahami terutama oleh pemula. ${ }^{7}$

Dalam pengajarannya, Metode 'Allimna memiliki perbedaan jilid. Metode Allimna mengajarkan dengan 5 jilid buku dan langsung diteruskan dengan al-Qur'an. Oleh karena itu peneliti tertarik melakukan penelitian terhadap penerapan Metode Alimna untuk anak kalangan TPQ. ${ }^{8}$

Taman Pendidikan al-Qur'an (TPQ) Al-Barokah adalah lembaga pembelajaran alQur'an yang menggunakan Metode 'Allimna. Taman Pendidikan al-Qur'an (TPQ) ini didirikan dikarenakan pendiri melihat kesadaran umat Islam saat ini khususnya di Kabupaten Jember dalam mempelajari al-Qur'an sangat tinggi sedangkan jumlah tempat pembelajaran Al-Qur'an tidak seimbang dengan banyaknya jumlah umat yang ingin belajar Al-Qur'an. Oleh karena itu Taman Pendidikan al-Qur'an (TPQ) Al-Barokah terpanggil untuk mewadahinya agar umat bisa lebih cepat belajar. Keistimewaan Taman Pendidikan al-Qur'an (TPQ) Al-Barokah daripada TPQ yang lain, TPQ Al-Barokah memiliki banyak sekali peserta didik mulai dari anak-anak, remaja sampai dewasa. ${ }^{9}$

Faktor yang melatar belakangi penelitian ini adalah Metode 'Allimna tidak hanya sekedar memberikan pembelajaran mengenai cara membaca al-Qur'an yang baik dan benar namun metode 'Allimna juga memberikan cara bagaimana seorang santri bisa membaca alQur'an dengan lancar. Keistimewaan Metode 'Allimna ini di samping penerapan metode

\footnotetext{
${ }^{7}$ Observasi, Karangbayat: Jember, 05 Februari 2020

8 Huda, Wawancara, Karangbayat, Jember, 03 Februari 2020
} 
pembelajaran al-Qur'an yang baik, sekaligus terdapat penanaman dasar-dasar akidah. Karena ayat-ayat yang dijadikan contoh bacaan adalah ayat-ayat yang terkait dengan dalil-dalil akidah dan amaliyah ahlussunnah waljama'ah al-Naadhiyah, misal dalil tawasul, tahlil, dan lain sebagainya. Metode 'Allimna menggunakan pendekatan dalam pengajarannya dan menggunakan nada- nada dalam membaca al-Qur'an sehingga membuat anak-anak menjadi senang dan nyaman, selain itu juga melalui metode 'Allimna setiap guru mampu memahami metodologi pengajaran al-Qur'an dan tahapan-tahapannya serta pengelolaan yang baik. ${ }^{10}$

Adapun fokus masalah penelitian ini akan membahas apa yang dimaksud metode 'Allimna untuk mempercepat baca al-Qur'an di Taman Pendidikan al-Qur'an (TPQ) AlBarokah Sumberbaru Kabupaten Jember? Bagaimana penerapan metode 'Allimna untuk mempercepat baca al-Qur'an di Taman Pendidikan al-Qur'an (TPQ) Al-Barokah Sumberbaru Kabupaten Jember? Apa yang menjadi faktor penghambat dan pendukung metode 'Allimna untuk mempercepat baca al-Qur'an di Taman Pendidikan al-Qur'an (TPQ) Al-Barokah Sumberbaru Kabupaten Jember?

\section{Pembahasan}

\section{Gambaran Objek Penelitian}

Dengan semakin bebasnya budaya luar yang masuk ditambah masuknya pergaulan di era globalisasi saat ini yang menyimpang, dirasa sangat perlu diadakan sebuah filterisasi dan benteng yang kuat untuk generasi Islam di zaman modern. Maka di Dusun Krajan Desa Karangbayat inilah dibentuk sebuah lembaga pendidikan yang berbasis keislaman, guna untuk membentengi para generasi muda dalam menerima budaya-budaya luar yang masuk.

Awalnya TPQ Al-Barokah ini hanya bertempat di Masjid dan santrinya masih sedikit, tetapi dengan berjalannya waktu dan minat dari warga sekitar hingga akhirnya lembaga ini mempunyai bangunan sendiri. Kemudian dengan adanya sistem dan metode pembelajaran yang tepat dalam mempelajari yang khususnya dalam membaca al-Qur'an, maka dibentuklah Taman Pendidikan al-Qur'an (TPQ) Al-Barokah oleh LP Ma'arif PCNU Jember pada tahun 2015, guna memberi wadah pada santri untuk belajar membaca al- Qur'an .

Pendidikan agama merupakan kunci utama dalam membentuk generasi muda yang bermoral dan berakhlakul karimah maka dengan adanya lembaga pendidikan agama di Desa Karangbayat khususnya diharapkan akan mampu mencetak generasi penerus perjuangan Bangsa yang mempunyai kualitas handal untuk memajukan kesejahteraan masyarakat.

\footnotetext{
${ }^{10}$ Huda, Wawancara, 03 Februari 2020
} 
Santri adalah salah satu komponen dalam pengajaran, di samping faktor guru, tujuan dan metode pengajaran yang terpenting. Maka data siswa TPQ Al-Barokah yang diperoleh oleh peneliti jumlah keseluruhannya adalah 70 santri, yang laki-laki jumlahnya 40, sedangkan perempuan jumlahnya 30 .

\section{Gambar 1.}

\section{Suasana Mengaji}

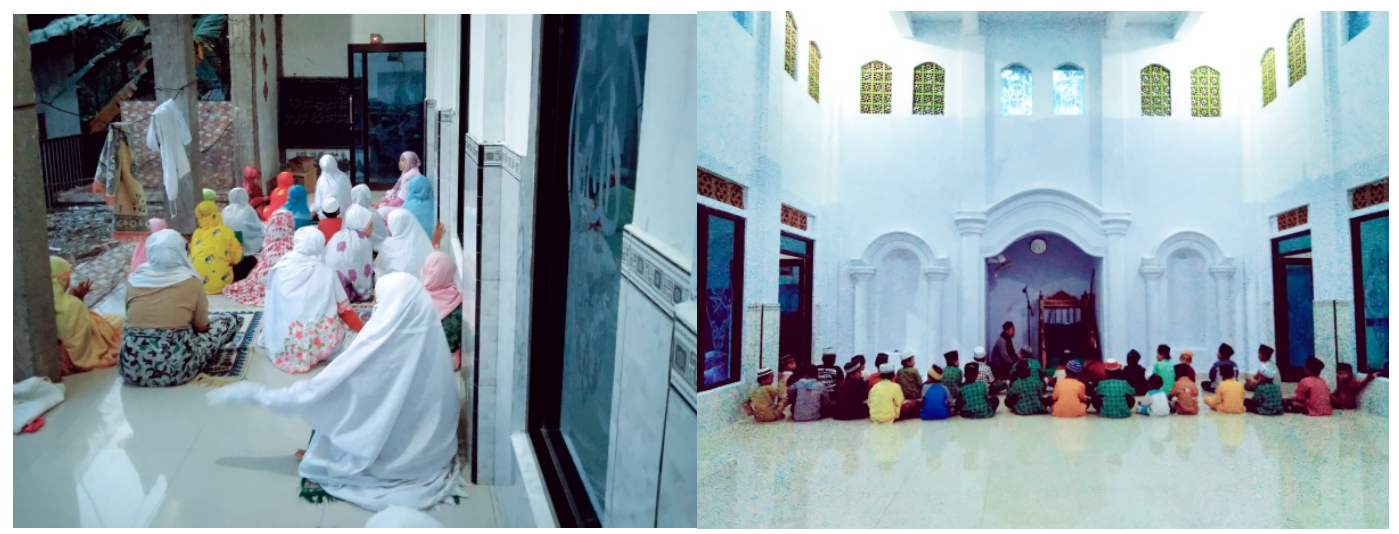

Sumber: Dokumentasi Pribadi

A. Penerapan Metode 'Allimna Untuk Mempercepat Baca Al-Qur'an Penggunaan metode 'Allimna dimulai dari jilid 1 sampai jilid 5. Peserta didik boleh melanjutkan ke jilid atau tingkat berikutnya jika peserta didik itu benar-benar menguasai dan lancar sarta tidak salah dalam pembacaannya, termasuk membaca latihan yang terdapat halaman akhir. Ada beberapa tahapan dalam metode 'Allimna tersebut, yaitu:

\section{Metode 'Allimna Jilid 1}

Guru memberi contoh melafalkan huruf Hamzah berbentuk alif atau tidak (Í) dan Ba' (ب). Guru juga menjelaskan Makhrajnya, Hamzah makhrajnya : pangkal tenggorokan, Ba' makhrajnya : dua bibir agak merapat. ${ }^{11}$

${ }^{11}$ M.Junaidi, Panduan Guru 'Allimna Metode Belajar Ngaji Al-Qur'an, (MABIN TPQ LP MA'ARIF NU CABANG JEMBER, 2019),1. 
Abdul Havid, Moch. Shohib

\section{Gambar 2.}

'Allimna Jilid 1

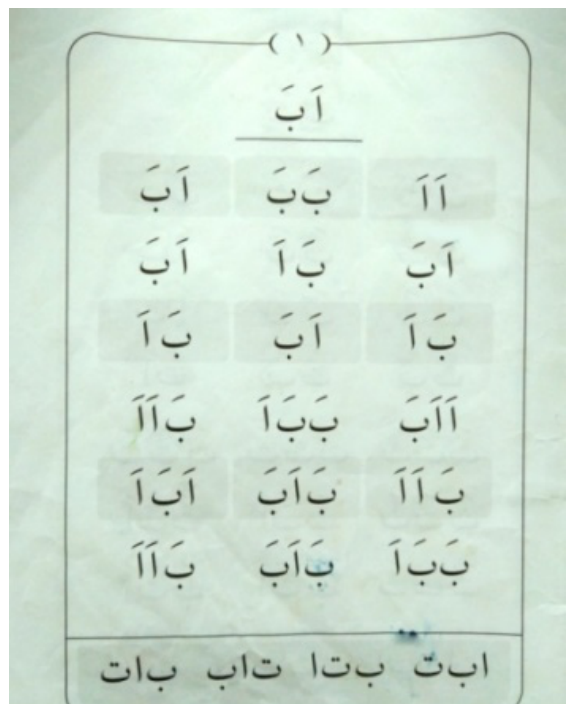

Sumber: Dokumentasi Pribadi

Selaku guru TPQ Al-Barokah Ustaz Waqi'atus Sholehah dalam menerapkan metode 'Allimna pada jilid Kedua mengatakan bahwa: "Metode yang saya terapkan pada anak kecil pertama mengenai lambang huruf Hijaiah berupa alif tegak atau lurus kedua mengenalkan lambang syakal atau harokat fathah yang selalu diulang-ulang dalam bacaan tersebut sampai ia paham dan benar bacaan dan makhrajnya" 12

Ismail salah satu santri yang masih tahap awal pada jilid pertama menuturkan bahwa :

"Yang saya tahu ustazah Waqi' itu dalam menerapkan metode 'Allimna ini, ia sering kali mengulangi bacaan-bacaan huruf hijaiah sampai tepat dan benar pada anak-anak yang masih belum bisa. Jika sudah tepat dalam bacaan dan makhrajnya maka ia akan dilanjutkan pada halaman berikutnya"13

2. Metode 'Allimna Jilid 2

Menjelaskan nama dan fungsi harakat ( tanda baca), katakan bahwa : fathah ()) bersuara "a", kasrah (9) bersuara "i" dan dlummah (ُ) bersuara "u". Coret satu di atas namanya fathah, Coret satu di bawah namanya kasrah dan yang seperti koma namanya dlummah. ${ }^{14}$

\footnotetext{
12 Waqi', Wawancara, Karangbayat: Jember, 20 April 2020

${ }^{13}$ Ismail, Wawancara, Karangbayat: Jember, 20 April 2020

${ }^{14}$ M.Junaidi, Panduan Guru 'Allimna,.... 10.
} 
Gambar 3.

'Allimna Jilid 2

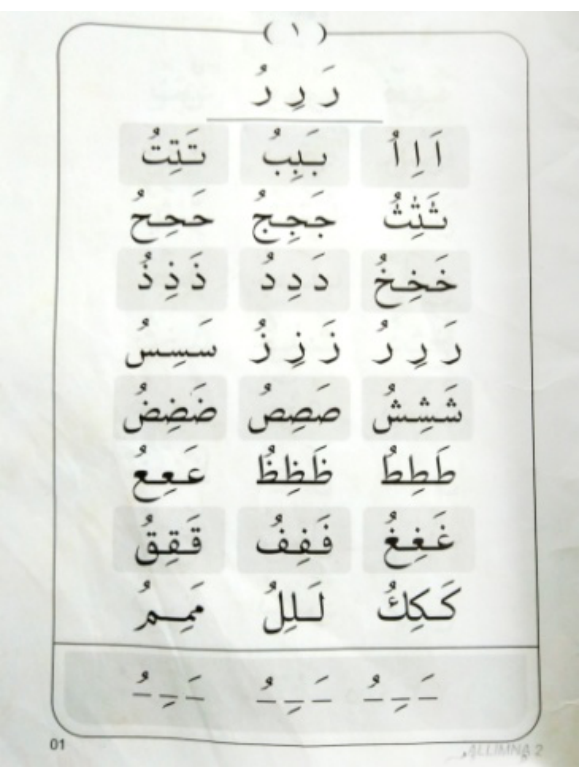

Sumber: Dokumentasi Pribadi

Ustaz Waqi'atus Sholehah dalam menerapkan metode 'Allimna pada jilid Kedua mengatakan bahwa: "Metode yang saya terapkan adalah menggunakan metode Shautiyah. Jadi saya hanya meneliti bacaan huruf hijaiah dan makhrojnya saja baik dalam segi harokat fathah, kasroh dan dhommah. Karena jilid ke dua ini hampir sama dengan jilid pertama, tapi jilid kedua ini saya banyak memberikan pencontohan bunyi bacaan huruf bersyakal beserta makhrojnya $" 15$

Hal senada yang dikatakan oleh Iza ia salah salah satu santri yang masih tahap awal pada jilid dua adalah: "Biasanya yang dilakukan oleh Waqi'itu mengulangi bacaan-bacaan huruf hijaiah yang sesuai dengan makhrojnya dan ia juga melatih tempat keluarnya huruf bacaan tersebut" 16

\section{Metode 'Allimna Jilid 3}

Menjelaskan bahwa tanda baca seperti ini (ّ) dinamakan Tasydid, setiap huruf yang bertasydid harus ditekan membacanya, karena huruf yang bertasydid berarti dua huruf sama (doble). ${ }^{17}$

\footnotetext{
${ }^{15}$ Waqi', Wawancara, Karangbayat: Jember, 20 April 2020

${ }^{16}$ Iza, Wawancara, Karangbayat: Jember, 20 April 2020

${ }^{17}$ M.Junaidi, Panduan Guru 'Allimna,....13.
} 
Abdul Havid, Moch. Shohib

\section{Gambar 4.}

'Allimna jilid 3

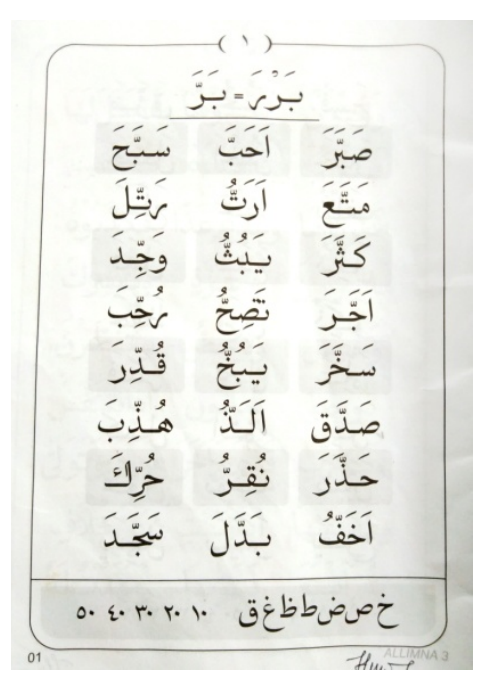

Sumber: Dukmentasi Pribadi

Ustaz Zainuddin dalam menerapkan metode 'Allimna pada jilid Ketiga mengatakan bahwa: "Ada beberapa cara yang saya lakukan lebih banyak mengarah pada bacaan bunyi huruf yang bertasydid, alif dan lam. pengembangannya yang diikuti oleh semua santri dan diteruskan dengan takrir atau pengulangan bacaan yang benar.”. ${ }^{18}$

Hal senada yang dikatakan oleh Dimas selaku santri TPQ Al-Barokah yang masih jilid tiga sebagai berikut: "Yang saya tahu bahwa yang dilakukan oleh Ustaz Zainuddin lebih banyak mengenal pada bunyi huruf yang bertasydid serta melafalkan bacaan dan diikuti oleh semua santri" 19

4. Metode 'Allimna Jilid 4

Menjelaskan tentang huruf Nun yang ketika bertasydid (ن) harus dibaca dengan menyertakan dengung yang lama (Ghunnah musyaddadah). ${ }^{20}$

\footnotetext{
${ }^{18}$ Zainuddin, Wawancara, Karangbayat: Jember, 20 April 2020

${ }^{19}$ Dimas, Wawancara, Karangbayat: Jember, 20 April 2020

${ }^{20}$ M.Junaidi, Panduan Guru 'Allimna,....17.

60 | IQ (Ilmu Al-qur'an): Jurnal Pendidikan Islam| Volume 4 No.01 2021, 51-74
} 


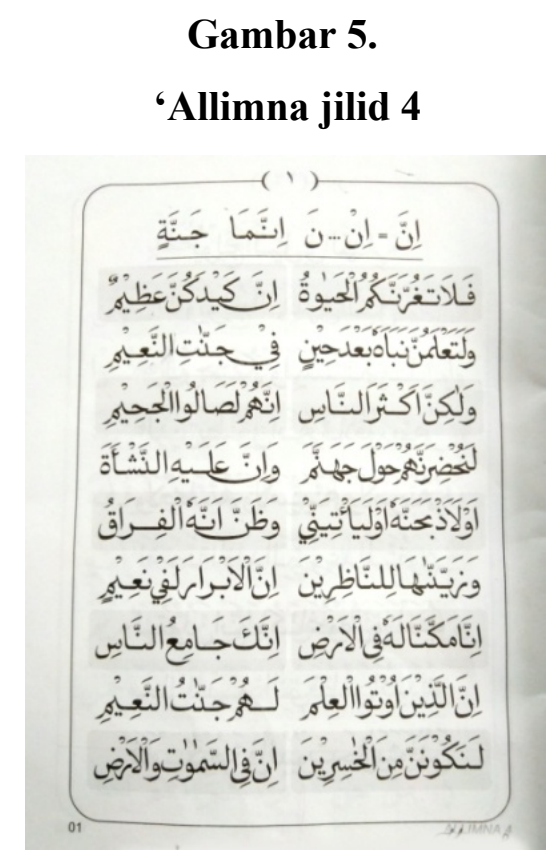

Sumber: Dukmentasi Pribadi

Ustaz Zainuddin dalam menerapkan metode 'Allimna pada jilid empat mengatakan bahwa: "Disaat saya ngajar 'Allimna jilid empat, maka yang saya terapkan mengenai hukum bacaan tajwid terutama santri dikenalkan dengan bacaan Ghunnah, Idhom Mimmi, Idhar, dan $i k h f a$ ' dan Iqlab. sebelum ditutup santri dan ustaz membiasakan membaca doa sesudah belajar" 21

Hal senada yang katakan oleh Rohma Wati selaku santri TPQ yang masih belajar 'Allimna jilid empat sebagai berikut: "Yang dikatakan oleh Ustaz Zainuddin itu benar bahwa pada jilid empat ini lebih banyak mengenal bacaan tajwid dan makhrajnya dan pada halaman akhir semua santri oleh ustazah di uji atau di latih kembali dalam bacaannya",22

\section{Metode 'Allimna Jilid 5}

Menjelaskan tentang cara berhenti (waqaf), apabila ada kalimat, huruf yang terakhir hidup dan huruf sebelumnya dibaca pendek, maka jika waqaf, huruf yang terakhir harus dimatikan dan huruf sebelumnya tetap dibaca pendek. ${ }^{23}$

\footnotetext{
${ }^{21}$ Zainuddin, Wawancara, Karangbayat: Jember, 20 April 2020

22 Rohma, Wawancara, Karangbayat: Jember, 20 April 2020

${ }^{23}$ M.Junaidi, Panduan Guru 'Allimna,....21.
} 
Gambar 6.

'Allimna jilid 5

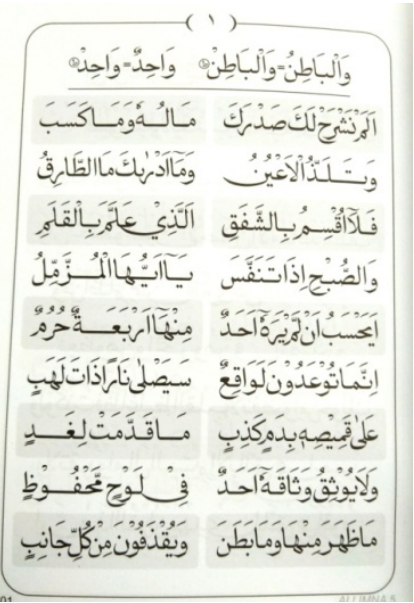

Sumber: Dukmentasi Pribadi

Ustaz Miftahul Huda dalam menerapkan metode 'Allimna pada jilid lima mengatakan bahwa :

"Strategi yang saya terapkan di TPQ salah satunya adalah menggunakan sistem gantian dari pihak guru yang membacakan ayat serta bertajwid dan di ikuti oleh semua santri. Setelah itu saya menunjuk santri satu persatu dengan mengulangi ayat yang sudah di baca”"24

Hal senada yang dikatakan oleh Fika selaku santri TPQ Al-Barokah adalah "Saya adalah salah santri yang diajari oleh Ustaz Miftahul Huda memang dalam pembelajaran 'Allimna ustaz menggunakan sistem gantian ia pertama membacakan ayat-ayat tersebut serta tajwidnya kemudian diikuti oleh santri secara bersamaan dan pada akhirnya ditunjuk satu persatu untuk mengulangi bacaan tersebut" 25

Dapat disimpulkan bahwa buku panduan 'Allimna yang diterapkan oleh guru TPQ AlBarokah untuk mempercepat baca al-Qur'an yang terdiri dari 5 jilid, Jilid Satu, penekanan pada: Huruf hijaiah 28 Membacanya dengan tepat. Jilid Dua, penekanan pada harokat: fathah, kasrah, dlomah, panjang pendek yang dua ketukan (mad tabi'i), huruf sambung, harokat; fathah tanwin, kasrah tanwin, dlomah tain, tidak boleh salah membaca huruf. Jilid Tiga, penekanan pada: tanda baca seperti tasydid, alif dan lam, qolqolah, Tidak boleh salah huruf dan panjang pendek harus lancar. Jilid Empat, penekanan pada: Bacaan dengung (ghunnah, idghom mimmi, ihkfa', iqlab), Panjang lima ketukan (mad wajib), Membaca dengan benar sesuai dengan kaidah tajwid al-Qur'an. Untuk jilid Lima, yaitu penekanan pada: cara berhenti

\footnotetext{
${ }^{24}$ Huda, Wawancara, Karangbayat: Jember, 20 April 2020

${ }^{25}$ Fika, Wawancara, Karangbayat: Jember, 20 April 2020

62 | IQ (Ilmu Al-qur'an): Jurnal Pendidikan Islam| Volume 4 No.01 2021, 51-74
} 
(waqof) Bacaan Makhraj dan Tajwidnya serta hukum bacaan nun mati atau tanwin yang berdasarkan qaidah yang berlaku.

Dalam pembelajaran metode "Allimna sistem yang diterapkan adalah klasikal dan individual. Sistem klasikal terdiri dari tiga teknik yaitu teknik pertama, guru membaca, santri mendengarkan, teknik kedua guru membaca santri menirukan, teknik ketiga membaca bersama-sama antara guru dan santri. Sama halnya ketika beberapa kali saya mengamati memang benar begitu adanya teknik ini diterapkan ketiga membaca peraga. Setiap kali pertemuan membaca minimal 5 halaman peraga yang berisikan pokok-pokok bahasan sesuai dengan bahasan yang ada di jilid. Setiap jilid memiliki peraga sendiri-sendiri dengan pokok bahasan sendiri-sendiri. Seperti yang dijelaskan oleh Ustaz Waqi'atus Sholehah bahwa:

"kami menggunakan teknik klasikal, baca simak atau privat dalam metode ini, sebelum memulai pembelajaran kami mengatur posisi duduk berbentuk ' $U$ ' untuk memudahkan kami mengawasi para santri ketika pelajaran berlangsung, kemudian memulai dengan membaca surat-surat pendek bagi semua santri baik yang masih jilid atau yang sudah al-Qur'an. Kami juga menggunakan peraga untuk setiap kali pertemuan dengan minimal membaca 5 halaman peraga untuk masing-masing jilid." ${ }^{26}$

Kegiatan pemberian materi penunjang selama 15 menit. Materi penunjang ini di antaranya yaitu hafalan ayat-ayat pilihan, bacaan salat, dan doa-doa harian serta surat-surat pendek. Kemudian Ustaz Zainuddin menjelaskan lebih rinci mengenai proses pembelajaran yang dilakukan di TPQ Al-Barokah.

"kegiatan pembelajaran di sini menggunakan teknik klasikal juga baca simak, sebelum memulai kegiatan awal yang dilakukan adalah mempersiapkan posisi duduk, salam, membaca doa, kemudian membaca surat-surat pendek atau doa-doa sehari-hari, bacaan niat salat dan wudu, baru kemudian penggunaan peraga untuk jilid satu sampai enam, yang pertama guru membaca santri mendengarkan, kedua guru membaca santri menirukan dan yang ketiga membaca secara bersama-sama antara guru dan santri. Setelah itu baru kegiatan baca simak individual antara guru dan santri dan doa serta salam penutup."27

Dari hasil wawancara di atas, menggambarkan bahwa guru melakukan teknik klasikal dan baca simak yang disesuaikan dengan penggunaan metode 'Allimna .

Di sini semua murid harus memiliki buku pegangan berupa jilid secara individu, agar semua siswa ketika membaca jilid dapat menyimak bukunya masing-masing sehingga

${ }^{26}$ Waqi', Wawancara, Karangbayat: Jember, 20 April 2020

27 Zainuddin, Wawancara, Karangbayat: Jember, 20 April 2020 
pembelajaran berjalan secara efektif dan efisien serta mampu mencapai tujuan yang diharapkan.

Hal ini sesuai pernyataan Ustaz Waqi'atus Sholehah “Jadi karena yang dibaca itu jilid, ya semua murid harus punya buku pegangan 'Allimna sendiri-sendiri, biar enak anak-anak bisa menyimak sendiri-sendiri. Kan jadinya bisa lebih efektif mas, dan pada setiap pembelajaran dengan penggunaan lagu itu lebih memudahkan para santri untuk belajar". ${ }^{28}$

Dari awal memang metode 'Allimna dirancang dengan menggunakan dua teknik. Yaitu dengan teknik klasikal dan individual yang diterapkan dengan teknik baca simak. Teknik baca simak dipraktikkan dengan satu siswa membaca 1 baris secara bergantian berurutan ke bawah hingga baris terakhir dan yang lainnya menyimak.

\section{Gambar 7.}

\section{Teknik Klasikal}

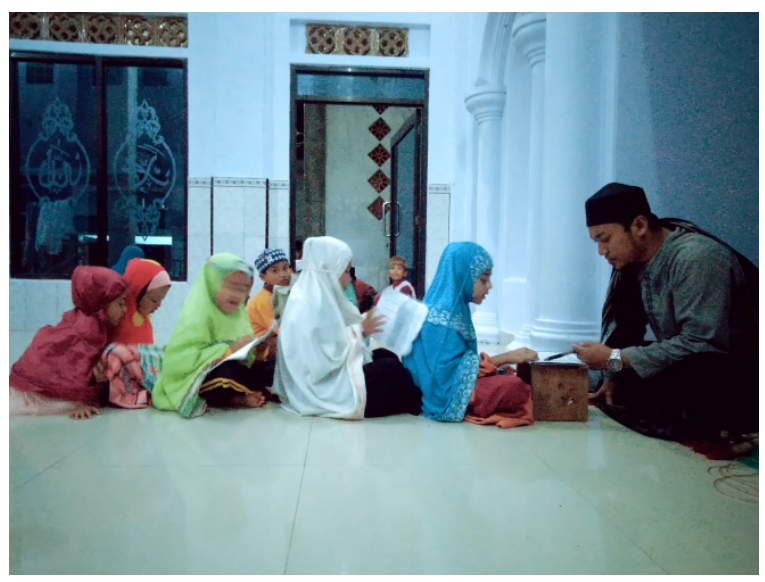

Sumber: Dukmentasi Pribadi

Teknik klasikal ini diterapkan dengan maksud agar proses pembelajaran dapat terlaksana secara efektif dan efisien sesuai dengan tujuan yang diharapkan. Hal tersebut sesuai dengan apa yang disampaikan oleh Ustaz Miftahul Huda Selaku Kepala Madrasah:

"Begini, kan teknik yang digunakan pada pembelajaran Al- Qur'an menggunakan metode 'Allimna ini ada 2, yaitu secara klasikal dan individual. Nah, kenapa kami kok menerapkan yang individual juga? Salah satu alasannya yaitu karena untuk mengatasi biasanya anak-anak kan senang bermain, memang itu masa-masa mereka. Teknik individual melalui baca simak ini diterapkan agar santri dapat tertib, tidak ramai dan tidak bermain sendiri. Kan kalau baca simak itu yang satu membaca dan yang lain menyimak sedangkan guru berperan sebagai pengontrol dan penilai". ${ }^{29}$

\section{Tabel 1.}

${ }^{28}$ Waqi', Wawancara, Karangbayat: Jember, 20 April 2020

${ }^{29}$ Huda, Wawancara, Karangbayat: Jember, 20 April 2020 


\section{Contoh teknik individual jilid pada $1 x$ pertemuan}

\begin{tabular}{|c|c|c|c|c|c|c|c|c|}
\hline \multirow[b]{2}{*}{$\begin{array}{c}\text { Santri } \\
\text { ke- }\end{array}$} & \multicolumn{8}{|c|}{ Buku jilid 3 halaman 1} \\
\hline & $\begin{array}{l}1 \\
\text { Baca } \\
\text { baris }\end{array}$ & $\begin{array}{l}2 \\
\text { Baca } \\
\text { baris }\end{array}$ & \begin{tabular}{|l}
3 \\
Baca \\
baris
\end{tabular} & $\begin{array}{l}4 \\
\text { Baca } \\
\text { baris }\end{array}$ & $\begin{array}{l}\text { P5 } \\
\text { Baca } \\
\text { baris }\end{array}$ & $\begin{array}{l}\text { P6 } \\
\text { Baca } \\
\text { baris }\end{array}$ & $\begin{array}{l}\text { P7 } \\
\text { Baca } \\
\text { baris }\end{array}$ & $\begin{array}{l}\text { P8 } \\
\text { Baca } \\
\text { baris }\end{array}$ \\
\hline 1 & 1 & 2 & 3 & 4 & 5 & 6 & 7 & 8 \\
\hline 2 & 2 & $\beta$ & 4 & 5 & 6 & 7 & 8 & 1 \\
\hline 3 & 3 & 4 & 5 & 6 & 7 & 8 & 1 & 2 \\
\hline 4 & 4 & 5 & 6 & 7 & 8 & 1 & 2 & 3 \\
\hline 5 & 5 & 5 & 7 & 8 & 1 & 2 & 3 & 4 \\
\hline 6 & 6 & 7 & 8 & 1 & 2 & 3 & 4 & 5 \\
\hline 7 & 7 & $\beta$ & 1 & 2 & 3 & 4 & 5 & 6 \\
\hline 8 & 8 & 1 & 2 & 3 & 4 & 5 & 6 & 7 \\
\hline
\end{tabular}

Penjelasan Pertemuan pertama membaca halaman pertama. Setelah teknik klasikal selesai, maka teknik terakhir yang ke empat yaitu teknik individual baca simak. Pada teknik ini misalnya ada 8 santri dalam satu kelompok belajar. Maka pada putaran pertama santri 1 membaca baris 1, kemudian santri 2 membaca baris 2, santri 3 membaca baris 3 dan seterusnya. Pada putaran kedua santri 1 membaca baris bawahnya yang tadi telah ia baca yaitu baris 2 , kemudian santri 2 membaca baris 3, santri 3 membaca baris 4, begitu seterusnya berputar hingga semua santri telah membaca satu halaman penuh. Santri pertama sebagai kunci membaca pada baris berapa dan siswa selanjutnya melanjutkan pada baris-baris bawahnya.

\section{Gambar 8.}

\section{Teknik Individual}

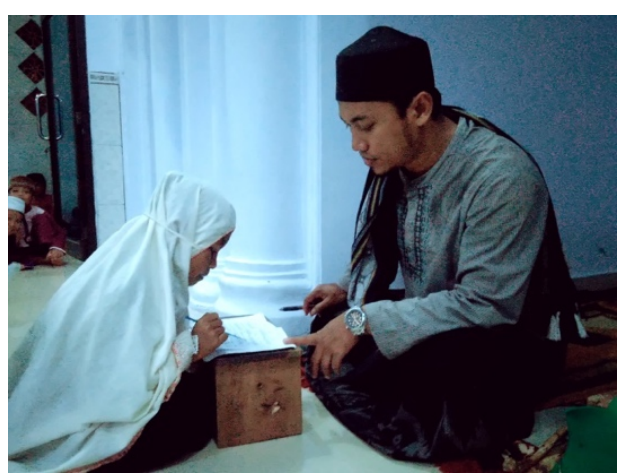

Sumber: Dukmentasi Pribadi

Hal ini seperti yang disampaikan oleh Ustaz Waqi'atus Sholehah: 
"Individualnya pakai teknik baca simak. Ya yang satu baca terus yang lainnya menyimak, satu baris satu baris memutar sampek semua kebagian baca kalo dijumlah penuh satu halaman. Sebenarnya sama saja dengan langsung membaca satu halaman penuh. Tapi ya ini teknik saja untuk menyiasati supaya anak-anak itu tidak ramai ataupun bermain sendiri". ${ }^{30}$

Penjelasan tersebut diperkuat oleh pernyataan dari Ustaz Zainuddin, dalam penggunaan peraga teknik baca simak sangat membantu guru untuk mengondisikan kelas supaya anak-anak itu tidak ramai sendiri saat belajar, karena mereka bergantian ada yang membaca dan membaca, jadi tidak ada kesempatan bagi mereka mengobrol sendiri. ${ }^{31}$

Evaluasi yang dilakukan setiap hari ini dilakukan oleh guru ketika teknik individual melalui teknik baca simak berlangsung. Jadi ketika teknik individual dengan baca simak berlangsung, inilah waktunya guru menilai bagaimana bacaan siswa. Apakah sudah baik atau belum. Penilaian harian dicatat pada buku prestasi santri yang dimiliki oleh setiap santri. Di dalam buku prestasi tersebut dicatatkan tanggal pembelajaran, peraga yang dibaca halaman berapa sampai berapa, kemudian halaman jilidnya, guru yang mengajar, paraf guru dan yang terakhir nilai santri dengan penilaian bentuk simbol A, B atau C. A untuk yang kategori membacanya lancar dengan baik dan benar, B untuk kategori yang kurang baik dan $\mathrm{C}$ untuk kategori yang belum baik. Begitu halnya yang diungkapkan Ustaz Miftahul Huda:

"ya ada buku prestasinya untuk evaluasi harian. Kan pas waktunya baca simak itu anakanak baca satu-persatu satu baris satu baris dengan bergilir memutar gitu, ya pada saat itu gurunya menilai. Nilainya ya sesuai dengan kemampuan bacanya, ada yang $\mathrm{A}$, ada yang $\mathrm{B}$, kalau yang $\mathrm{C}$ jarang sekali, dan setelah diketahui penilaian hasil belajarnya melalui ujian atau tes bacaannya satu persatu kemudian tidak secara klasikal pada umumnya evaluasi yang ada dalam teori metode 'Allimna, namun secara individual dapat diputuskan oleh guru apakah anak ini dinaikkan ke jilid berikutnya atau tinggal dulu di jilid tersebut". ${ }^{32}$

Kesimpulannya dari uraian di atas, di TPQ Al-Barokah Sumberbaru selain menggunakan teknik klasikal dan baca simak secara individual, tetapi juga terdapat pelajaran tambahan yang bersifat praktis berupa melafalkan surat-surat pendek pilihan, doa sehari-hari serta bacaan niat salat dan wudu supaya mereka dapat mengamalkannya di kehidupan sehari hari, dan dengan adanya penilaian atau evaluasi melalui tes bacaan secara individu guru dapat mengetahui seberapa kemampuan dan pemahaman santri dalam pembelajaran al-Qur'annya.

\section{B. Faktor Penghambat dan Pendukung Penerapan Metode 'Allimna Untuk Mempercepat Baca Al-Qur’an di TPQ Al-Barokah Sumberbaru}

\footnotetext{
${ }^{30}$ Waqi', Wawancara, Karangbayat: Jember, 20 April 2020

${ }^{31}$ Zainuddin, Wawancara, Karangbayat: Jember, 20 April 2020

${ }^{32}$ Huda, Wawancara, Karangbayat: Jember, 20 April 2020
} 


\section{Penghambat}

\section{a. Peserta Didik}

Lancar tidaknya suatu pendidikan juga tergantung pada peserta didik itu sendiri, karena apabila mereka mempunyai kemauan dan niat untuk belajar dengan sungguh-sungguh dalam menekuni pengetahuan sesuai dengan kemampuannya maka akan mendukung proses pendidikan dan tentunya tidak akan mengalami kesulitan. Begitu pula sebaliknya apabila dalam diri peserta didik tidak ada kemauan untuk belajar dan tidak mau mengembangkan kemampuannya maka akan menghambat proses pendidikan dan peserta didik cenderung mengalami kesulitan belajar. Seperti yang diungkapkan oleh Ustaz Waqi'atus Sholehah:

"Lancar tidaknya suatu pendidikan itu tergantung anaknya sendiri, kalau mereka mau belajar pasti bisa. Tapi terkadang kalau sudah di rumah itu sudah malas untuk belajar, dan juga jika waktu mengaji itu bersamaan sama kegiatan les jadi siswa lebih memilih untuk pergi ke tempat les dari pada ke madrasah". ${ }^{33}$

Hal ini sama halnya seperti yang diungkapkan oleh Ustaz Zainuddin "anak-anak itu kalau sudah di rumah sudah malas belajar, seperti halnya anak saya kalau sudah pulang sekolah inginnya main susah sekali disuruh belajar". ${ }^{34}$

Dari paparan di atas menggambarkan bahwa peserta didik itu sendiri juga berpengaruh terhadap proses pendidikan, kebanyakan dari mereka sudah malas kalau harus belajar lagi di rumah, mereka hanya mengandalkan pembelajaran ketika di TPQ saja, oleh karena itu para orang tua harus ikut berperan aktif dalam mendorong kegiatan belajar siswa ketika di rumah.

\section{b. Pengajar}

Pengajar atau guru juga menentukan berhasil tidaknya suatu pendidikan, karena guru juga bertanggung jawab dalam pembentukan pribadi siswa, guru harus memiliki pengetahuan mengenai apa yang akan diajarkannya dan berkompetensi agar tugas yang diembannya dapat tercapai dengan baik, Ustaz Miftahul Huda mengatakan bahwa:

"Guru juga menjadi faktor berhasil tidaknya pembelajaran. Jumlah guru dan kehadirannya sangat berpengaruh terhadap proses pembelajaran di TPQ, itu menjadi kendala karena keterbatasan guru di sini apalagi kalau pas ada guru yang tidak hadir guru tersebut harus bilang ke guru yang lain yang tidak ada jadwal pada hari itu untuk mengajar. Di sini guru juga harus memiliki pengetahuan yang luas mengenai hal bacaan al-Qur'an terutama dengan penggunaan metode 'Allimna maka dengan itu akan lebih mudah untuk mengajarkan pada anak-anak."35

\footnotetext{
${ }^{33}$ Waqi', Wawancara, Karangbayat: Jember, 20 April 2020

${ }^{34}$ Zainuddin, Wawancara, Karangbayat: Jember, 20 April 2020

${ }^{35}$ Huda, Wawancara, Karangbayat: Jember, 20 April 2020
} 
Benar sekali ungkapan dari Ustaz Miftahul Huda, ternyata guru atau pengajar juga sangat menentukan dalam mencapai keberhasilan. Keberhasilan tidak akan dapat diraih jika guru tidak dapat berperan serta dalam proses pendidikan.

c. Lingkungan Keluarga

Lingkungan keluarga sangat berpengaruh terhadap perkembangan peserta didik. Pengaruh lingkungan terutama keluarga dapat dikatakan negatif jika di rumah tidak terdapat dorongan dari orang tua untuk membimbing anaknya belajar. Sebagaimana hasil wawancara dengan Ustaz Zainuddin

"Lingkungan keluarga sangat mempengaruhi perkembangan pendidikan pada anak. Apabila di rumah orang tua tidak rajin mengajarkan anaknya bacaan al-Qur'an maka anak-anak kesulitan dalam membaca al-Qur'an". ${ }^{36}$

Ibu Suyatin Menambahkan:

"Anak itu juga tergantung pembelajarannya dirumah, kalau orang tuanya saja malas untuk mengajari anak belajar tentu anak itu juga akan ikut-ikut malas karena kesulitan belajar. Dan jika hanya mengandalkan pembelajaran di TPQ maka anak akan lambat dalam pembelajarannya, maka itu perlu diperkuat dengan dukungan orang tua". ${ }^{37}$

Dari hal yang telah disampaikan tersebut, begitu jelas bahwa lingkungan keluarga dapat menjadi faktor penghambat bagi anak dalam mempelajari al-Qur'an di TPQ Al-Barokah Sumberbaru.

\section{Pendukung}

\section{a. Peserta Didik}

Lancar tidaknya suatu pendidikan juga tergantung pada peserta didik itu sendiri, karena jika mereka mempunyai kemauan dan niat untuk belajar dengan sungguh-sungguh dalam menekuni pengetahuan sesuai dengan kemampuannya maka akan mendukung proses pendidikan dan tentunya tidak akan mengalami kesulitan dalam belajar.

Seperti yang dikatakan oleh Ustaz Waqi'atus Sholehah

"Lancar atau tidaknya suatu pendidikan tergantung pada anaknya, jika mereka mau berusaha dan belajar di rumah maka tentunya tidak akan mengalami kesulitan dalam membaca al-Qur'an di TPQ. Santri di sini aktif dalam mengikuti pembelajaran mereka sangat kompak bersama- sama, meskipun ada beberapa yang tidak masuk tetapi pelajaran tetap berlangsung seperti biasanya". ${ }^{38}$

\footnotetext{
${ }^{36}$ Zainuddin, Wawancara, Karangbayat: Jember, 20 April 2020

37 Suyatin, Wawancara, Karangbayat: Jember, 20 April 2020

38 Waqi', Wawancara, Karangbayat: Jember, 20 April 2020

68 | IQ (Ilmu Al-qur'an): Jurnal Pendidikan Islam| Volume 4 No.01 2021, 51-74
} 
Dari ungkapan di atas bahwa rajin atau tidaknya peserta didik dalam belajar al-Qur'an akan berpengaruh terhadap kemampuan mereka sendiri, apabila di rumah mereka rajin belajar dan membaca al-Qur'an maka mereka tidak akan mengalami kesulitan untuk membacanya.

b. Pengajar

Pengajar atau guru juga menentukan berhasil tidaknya suatu pendidikan, karena guru juga bertanggung jawab dalam pembentukan pribadi santri, guru harus memiliki pengetahuan mengenai apa yang akan diajarkannya dan berkompetensi agar tugas yang diembannya dapat tercapai dengan baik, Ustaz Waqi'atus Sholehah mengatakan bahwa:

“Di sini guru harus memiliki pengetahuan yang luas mengenai hal bacaan al-Qur'an terutama dengan penggunaan metode tilawati, jadi kalau gurunya berpengetahuan maka dengan itu akan lebih mudah untuk mengajarkan pada anak-anak." ${ }^{39}$

Ternyata pengetahuan guru juga sangat menentukan dalam tingkat pencapaian dan keberhasilan suatu pendidikan. Keberhasilan tidak akan bisa diraih jika pengetahuan yang dimiliki pendidiknya hanya pas-pasan.

\section{c. Lingkungan Keluarga}

Lingkungan keluarga sangat berpengaruh dalam perkembangan peserta didik. Pengaruh lingkungan dikatakan positif jika lingkungan itu dapat memberikan rangsangan atau dorongan motivasi terhadap anak untuk rajin dalam belajar. Sebagaimana hasil wawancara dengan Ustaz Zainuddin;

"lingkungan keluarga sangat mempengaruhi perkembangan pendidikan pada anak. Apabila di rumah orang tua sering mengajarkan anaknya membaca al-Qur'an maka anak-anak tidak akan mengalami kesulitan dalam membaca al-Qur'an". ${ }^{40}$

Ibu Suyatin menambahkan:

“Anak itu juga tergantung pembelajarannya di rumah, kalau orang tuanya sering mengajari anak belajar tentu anak itu juga tidak akan mengalami kesulitan. Karena jika hanya mengandalkan pembelajaran di TPQ maka anak akan lambat dan tidak dapat maksimal dalam pembelajarannya, maka itu perlu diperkuat dengan dukungan orang tua". 41

Begitu jelas bahwa faktor lingkungan, terutama keluarga sangat berpengaruh terhadap kemampuan anak sebagi faktor pendukung yang utama dalam mempelajari al-Qur'an di TPQ Al-Barokah Sumberbaru.

Berdasarkan dari pemaparan data yang diperoleh dari hasil penelitian di atas mengenai Penerapan Metode 'Allimna untuk mempercepat baca al-Qur'an di TPQ Al-Barokah Sumberbaru yaitu:

\footnotetext{
${ }^{39}$ Waqi', Wawancara, Karangbayat: Jember, 20 April 2020

${ }^{40}$ Zainuddin, Wawancara, Karangbayat: Jember, 20 April 2020

${ }^{41}$ Suyatin, Wawancara, Karangbayat: Jember, 20 April 2020
} 


\section{Pengertian Metode 'Allimna}

Dari paparan data lapangan terkait dengan fokus penelitian yang pertama di atas bahwa perencanaan pembelajaran al-Qur'an dalam sistem pembelajaran di suatu lembaga memakai metode yang berbeda-beda. Termasuk di TPQ Al-Barokah Sumberbaru dalam pembelajaran al-Qur'an dengan penggunaan metode 'Allimna.

Metode 'Allimna adalah salah satu metode pembelajaran membaca al-Qur'an yang sudah berkembang di Kabupaten Jember. Metode 'Allimna merupakan karya original LP Ma'arif PCNU Jember yang diketahui pengasuh KH. Muhyiddin Abdusshomad adalah Rois syuriah PCNU Jember dan Gus Robith Qoshidi Muhyiddin,Lc adalah wakil ketua LP Ma'arif Jember. Metode 'Allimna tidak hanya menawarkan metode cepat, ternyata pilihan-pilhan ayat 'Allimna banyak yang menjadi argumentasi akidah dan amaliyah Ahlussunnah Wal Jama'ah. Jadi, bagi warga Nahdliyyin sudah selayaknya menggunakan 'Allimna di dalam proses belajar mengajar al-Qur'an. Bukan hanya bisa membaca al-Qur'an secara cepat, tetapi juga bisa memperkuat akidah Aswaja. Metode ini sangat cocok digunakan untuk pemula karena masih menggunakan nada yang sederhana.

2. Penerapan Metode 'Allimna

Dari data yang diperoleh di lapangan dalam pembelajaran metode 'Allimna sistem yang diterapkan, pertama adalah klasikal dan baca simak. Prinsip pelaksanaan pembelajaran al-Qur'an dengan metode 'Allimna diajarkan menggunakan lagu dengan materi penunjang membaca surat-surat pendek atau doa sehari-hari, bacaan niat salat dan wudu, baru kemudian diajarkan secara klasikal dengan menggunakan peraga.

Kedua, langkah yang dilakukan sebelum memulai pembelajaran peserta didik mengatur posisi duduk dengan berbentuk "U" untuk mempermudah guru dalam mengawasi proses pembelajaran yang berlangsung dan, ketiga di setiap akhir pembelajaran guru melakukan evaluasi dengan teknik baca simak individual untuk mengetahui kemampuan peserta didik.

\section{Tantangan Penerapan Metode 'Allimna}

Setiap aktifitas dalam upaya mengembangkan dibidang keilmuan senantiasa dipengaruhi oleh banyak hal baik itu penghambat maupun pendukung, demikian juga halnya dengan penerapan metode 'Allimna untuk mempercepat baca al-Qur'an di TPQ Al-Barokah Sumberbaru, yang pertama ada hal yang menjadi penghambat pelaksanaan tujuan pembelajaran di antaranya sebagai berikut:

a. Peserta didik, santri malas untuk mengulang atau mempelajari kembali pelajaran 
dirumah, bersamaan dengan kegiatan les.

b. Pengajar (guru), jumlah pengajar yang terbatas

c. Lingkungan keluarga, orang tua kurang memperhatikan anak ketika dirumah apakah mereka belajar atau tidak.

Yang kedua juga adanya hal yang mempengaruhi keberhasilan atau pendukung tujuan pembelajaran di TPQ Al-Barokah dari penerapan metode 'Allimna adalah sebagai berikut:

a. Peserta didik, para santri rajin dalam setiap mengikuti pembelajaran di TPQ

b. Pengajar (guru), guru memiliki pengetahuan mengenai metode 'Allimna, tlaten dan sabar dalam pembelajaran

Lingkungan keluarga, adanya dukungan dari orang tua untuk belajar di TPQ AlBarokah Sumberbaru.

\section{Kesimpulan}

Setelah pembahasan dan analisis pada bab-bab sebelumnya, maka dapat di tarik kesimpulan yaitu:

1. Pengertian Metode 'Allimna Untuk Mempercepat Baca Al-Qur'an di Taman Pendidikan al-Qur'an (TPQ) Al-Barokah Sumberbaru Jember adalah karya orisinil LP Ma'arif PCNU Jember yang diketahui pengasuh KH. Muhyiddin Abdusshomad adalah Rois syuriah PCNU Jember dan Gus Robith Qoshidi Muhyiddin,Lc adalah wakil ketua LP Ma'arif Jember. Metode 'Allimna tidak hanya menawarkan metode cepat, ternyata pilihan-pilhan ayat 'Allimna banyak yang menjadi argumentasi akidah dan amaliyah Ahlussunnah Wal Jama'ah. Jadi, bagi warga Nahdliyyin sudah selayaknya menggunakan 'Allimna di dalam proses belajar mengajar Al-Qur'an. Bukan hanya bisa membaca Al-Qur'an secara cepat, tetapi juga bisa memperkuat akidah Aswaja. Metode ini sangat cocok digunakan untuk pemula karena masih menggunakan nada yang sederhana.

2. Penerapan Metode 'Allimna Untuk Mempercepat Baca Al-Qur'an di Taman Pendidikan al-Qur'an (TPQ) Al-Barokah Sumberbaru Jember adalah menggunakan metode 'allimna dengan maksud agar dapat mencapai hasil yang lebih baik dan langkah-langkah yang pertama dalam melakukan pengenalan huruf Hijaiah dan makhrojnya, kedua adalah pengenalan harokah, ketiga adalah pengenalan huruf bersambung dan keempat pengenalan ilmu Tajwid 
3. Faktor Penghambat dan Pendukung Penerapan Metode 'Allimna Untuk Mempercepat Baca Al-Qur'an di TPQ Al-Barokah Sumberbaru, yaitu :

a. Penghambat

1) Peserta didik, santri malas untuk mengulang atau mempelajari kembali pelajaran dirumah, bersamaan dengan kegiatan les.

2) Pengajar (guru), jumlah pengajar yang terbatas

3) Lingkungan keluarga, orang tua kurang memperhatikan anak ketika dirumah apakah mereka belajar atau tidak.

b. Pendukung

1) Peserta didik, para santri rajin dalam setiap mengikuti pembelajaran di TPQ

2) Pengajar (guru), guru memiliki pengetahuan mengenai metode 'allimna, tlaten dan sabar dalam pembelajaran

3) Lingkungan keluarga, adanya dukungan dari orang tua untuk belajar di TPQ AlBarokah Sumberbaru.

\section{Saran}

Untuk memberikan sumbangan pikiran, maka penulis memberikan saran kepada TPQ Al-Barokah Sumberbaru Jember:

1. Sebagai pemimpin yayasan TPQ Al-Barokah selayaknya harus pandai dalam mengetahui peluang untuk mengambil kesempatan di berbagai macam kegiatan demi meningkatkan kemampuan dalam membaca dan pemahaman al-Qur'an oleh santri TPQ Al-Barokah.

2. Pendidik diharapkan lebih kreatif dan lebih progesif dalam meningkatkan kemampuan membaca dan pemahaman Al-Qur'an terhadap anak didiknya.

Agar peningkatan kemampuan membaca dan pemahaman Al-Qur'an dapat berjalan dengan baik, maka dari itu, untuk meningkatkan yang lebih baik semua pihak baik orang tua, guru maupun santri itu sendiri harus saling berhubungan. Karena ketiganya sangat berpengaruh pada perkembangan santri itu sendiri.

\section{Daftar Pustaka}

Abdurohim, Acep Lim. 2012. Ilmu Tajwid Lengkap. Bandung: CV Penerbit Diponegoro. Adhim, Said Abdul Adhim. 2009. Nikmatnya Membaca Al-qur'an. Solo: Anggota SPI. Arif, Armai. 2002. Pengantar Ilmu dan dan metode Pendidikan Islam. Jakarta: Ciputat Pers. 
Arindawati, Anika Erlina dan Hasbullah Huda. 2004. Beberapa Altenatif Pembelajaran di Sekolah Dasar. Malang: Banyu Publishing.

Asmad. 2013. Strategi Kyai Rosad Dalam Mengembangkan Minat Membaca al-Qur'an. IAIS. Bahrul Ulum, Urgensi kemampuan siswa membaca al-Qur'an dalam meningkatkan prestasi belajar al-Qur'an Hadist (Pandanwangi: STAIS 2012), 93.

Channa, Liliek. 2010. 'Ulum al-Quran dan Pembelajarannya. Surabaya: Kopertais IV Press. Farid, Achmad Farid. 2012. MetodeTakrir dalam Mempertahankan Hafalan al-Qur'an Santri Tahfidzul Qur'an Putra Pondok Pesantren Nurul Qur'an Kraksan Probolinggo”. Skripsi. Fakultas Tarbiyah dan Keguruan Kraksan: STAIS.

Hambali. 2013. Cinta Al-Qur'an Para Hafizh Cilik. Jogjakarta: Najah.

Hariri. 2008. Motivasi Mahasiswa dalam Menghafal al-Qur'an di Pondok Pesantren Salafiyah

Syafi'iyah Nurul Huda Mergosono Malang”, Skripsi, Fakultas Tarbiyah dan Keguruan UIN Maulana MalikIbrohim.

http:pesantrennuris.net/2016/10/09/allimna-metode-cepat-belajar-al-quran-karya-lp-maarif-

pcnu-jember/,diakses pada tanggal 10 februari 2020

KBBI Online, diakses 09 Februari 2020

Khalīl al-Qatțān, Mannā. 2012. Studi Ilmu-Ilmu al-Qur'an. Surabaya: CV. Ramsa Putra.

M.Junaidi, Panduan Guru 'Allimna Metode Belajar Ngaji Al-Qur'an, (MABIN TPQ LP MA'ARIF NU CABANG JEMBER, 2019),1.

Majid, Abdul. 2012. Belajar dan Pembelajaran Pendidikan Agama Islam. Bandung: PT Remaja Rosdakarya.

Masjfuk Zuhdi, Pengantar Ulumul Qur'an (Surabaya: Karya Abditama,1997),

Nasih, Ahmad Munjin dan Lilik Nur Kholidah. 2009. Metode dan Teknik Pembelajaran Pendidikan Agama Islam. Bandung: PT Refika Aditama.

Novi, Andrani. Mahasiswa IAIN Purwokerto, dengan judul penelitian Efektivitas Penerapan Metode Ummi Pada Pembelajaran Qira'atul Quran Di Mi Istiqomah Sambas Purbalingga. Skripsi.

Observasi, 2020. Karangbayat: Jember

Ramayulius. 2006. Ilmu Pendidikan Islam. Jakarta: Kalam Mulia.

Said Abdul Adhim, Nikmatnya Membaca Al-qur'an (Solo: Anggota SPI, 2009)

Syarifuddin, Ahmad. Mendidik Anak Membaca, Menulis, dan Mencintai Al-Qur'an. Jakarta: Gema Insani Press

Tafsir, Ahmad. 1996. Metodologi Pengajaran Agama Islam. Bandung: Remaja Rosdakarya. 
Abdul Havid, Moch. Shohib

Tarigan, Henry Guntur. 2008. Membaca Sebagai Suatu Keterampilan Berbahasa. Angkasa Bandung: Bandung.

Taufiqurrahman. 2005. Metode Jibril Metode PIQ-Singosari Bimbingan KHM. Bashori Alwi Malang: IKAPIQ Malang.

Tim penyusun, 2011. Panduan Penulisan Karya Ilmiah Iai Syarifuddin: LP3M.

Ulum, Bahrul Ulum. 2012. Urgensi kemampuan siswa membaca al-Qur'an dalam meningkatkan prestasi belajar al-Qur'an Hadist. Pandanwangi: STAIS.

Usman, Basyirudin. 2002. Metodologi Pembelajaran Agama Islam. Jakarta: Ciputat Pers.

Wahid, Wiwi Alwiyah. 2012. Cara Cepat Bisa Menghafal al-Qur'an. Jogjakarta: DIVA Press.

Zuhairini dkk. 1993. Metodik Khusus Pendidikan Agama. Surabaya: Usaha Nasional.

Zuhdi, Masjfuk. 1997. Pengantar Ulumul Qur'an . Surabaya: Karya Abditama. 